\title{
Possibilities of using innovative urban design approaches for economic regional development
}

\author{
Richard Jankura ${ }^{1, *}$, and Viktor Soltes ${ }^{1}$ \\ ${ }^{1}$ University of Zilina, Faculty of Security Engineering, Univerzitna 1, 01026 Zilina, Slovakia
}

\begin{abstract}
.
Research background: Globalization affects the daily lives of every individual, and therefore of the society in which he lives. In the coming years, almost $80 \%$ of the population will live in cities, which will have an impact on the socio-economic development of cities. These facts can lead to a deterioration of the security situation. Therefore, cities focused on the design of urban development, and thus on the elimination of undesirable factors.

Purpose of the article: Cities around the world began to attend with architectural modifications of spaces, which could positively influence socio-economic factors. Changing the environment can reduce crime in localities. The purpose of the article is to analyze the impact of selected approaches on the quality of citizens' life and to point out the possibilities of crime prevention through environmental design.

Methods: Solution that deals with influencing the urban environment is the CPTED method. This approach focuses on the urban space and the principles of the fight against crime. The article describes the principles of CPTED application in urban space, and ways of its possible use. The methods of economic analysis and mathematical statistics will also evaluate the economic impacts on the budget of the entity using the approach.

Findings \& Value added: Due to globalization, built-up areas in cities are expanding. These changes have implications for socio-economic factors. The findings can be used in the design of new as well as existing urban spaces by public administration entities (especially regional and local governments), but also by private developers.
\end{abstract}

Keywords: globalization; economic; CPTED; urban design; crime.

JEL Classification: $O 18$; $Q 56 ; R 58$

\footnotetext{
*Corresponding author: richard.jankura@fbi.uniza.sk
} 


\section{Introduction}

The impact of globalization affects several areas of ordinary life. It is possible to talk about positive globalization, but also negative. Positive globalization affects the economic, technological, cultural, or political convergence of the subjects of international relations. Contrariwise, negative globalization brings phenomena that can have an impact on the overall security of people. These can be a crime such as organized crime, the arms trade, or even terrorism [1]. One of the areas affected by globalization is the urban environment and its development. According to the European Commission, it is necessary to focus on urban issues. It is estimated that by $2020,80 \%$ of people will live in cities [2]. In the current decade, up to $50 \%$ of the world's population lives in cities and $38 \%$ live in urban areas [3]. These factors can affect not only the economic and social development of cities but also the security of people and their quality of life [4]. As a result, in recent years, more emphasis has begun to be placed on the evaluation of urban development, through which undesirable factors can be regulated [5]. The new approaches are aimed at managing, planning, and researching spatial engineering factors and their implications for the values of urbanization and the values of increasing crime [6].

\subsection{Impact of globalization on the security of the urban environment}

Globalization brings many challenges. One of them is urbanization and its impact on security. According to the United Nations, by 2050 the world's urban population will almost double. Urbanization will thus become one of the most important transformation trends in the 21 st century. This development can also be linked to widespread problems in the areas of housing, infrastructure, education, natural resources, and security [7]. The analysis of urban security can be assessed in terms of the relationship to the physical, environmental, social, cultural, economic, and political environment [8]. The importance of urban security and protection is contextual, as it is undoubtedly influenced by global and national factors [9].

The development of the urban environment has also brought with it a greater possibility of committing a crime [7]. Crime is a social phenomenon and characteristic features of contemporary crime include organization, intellectualization, sophistication, and internationalization with tendencies toward its globalization [1]. Among the most common crimes in connection with the urban environment is property crime, then violent crime [10, 11]. The relationship between the urban environment and the risk factors for crime and violence has only recently been pointed out. There is growing evidence that poor planning, design, and management of the environment exposes citizens to increased crime [12]. In the relationship between the urban environment and crime, it is then possible to define the following types of areas [13, 14]:

- Crime generators - are places where many people are, but they do not have predetermined motivation and act at appropriate crime opportunities.

- Crime attractors - are places that create opportunities for potential prepared offenders. These areas include department stores, railway stations, affluent neighborhoods, etc.

- Crime detractors - are places that deter offenders and prevents crime. It is possible to talk about places with enough control and suitable elements of protection.

There are several ways to approach crime prevention and reduction through environmental design. Several empirical studies suggest that physical design and management of the built environment play a role in facilitating or reducing opportunities for a crime $[13,15,16,17]$. The following section will describe some theories that deal with this issue. 


\subsubsection{Urban environment and crime prevention}

As early as the 1950s, there was start talk of crime prevention through proper urban planning and architectural design. One of the first theories, which is based on the rules that built - up space can lead to a reduction in crime is defensible space [18]. Newman defined "defensible space" as, a residential environment whose physical characteristics building layout, and site plan, function to allow inhabitants themselves to become key agents in ensuring security [13]. Newman identified four elements of defensible space, namely territoriality, natural surveillance, image, and environment [18].

Defensible space was the basis for the idea of the CPTED concept (Crime Prevention through Environmental Design) and talks about how cities and neighborhoods can be designed to reduce the factors that contribute to crime and violence itself [12]. The CPTED concept was first used by Jeffery [19]. CPTED is a methodology used since the 1960s to prevent crime [17]. Later, other possibilities for the CPTED concept were formed, and eventually, the second and third generations emerged $[17,20]$.

The CPTED concept is based on several principles that must be followed when designing a suitable environment that would reduce crime. The concept is mainly focused on increasing territoriality, surveillance, access control, and image management $[13,14]$. Some other authors have extended these principles to others, namely Target Hardening, Legitimate activity support $[13,17,20]$. The individual principles of the CPTED concept are shown in the following figure 1.

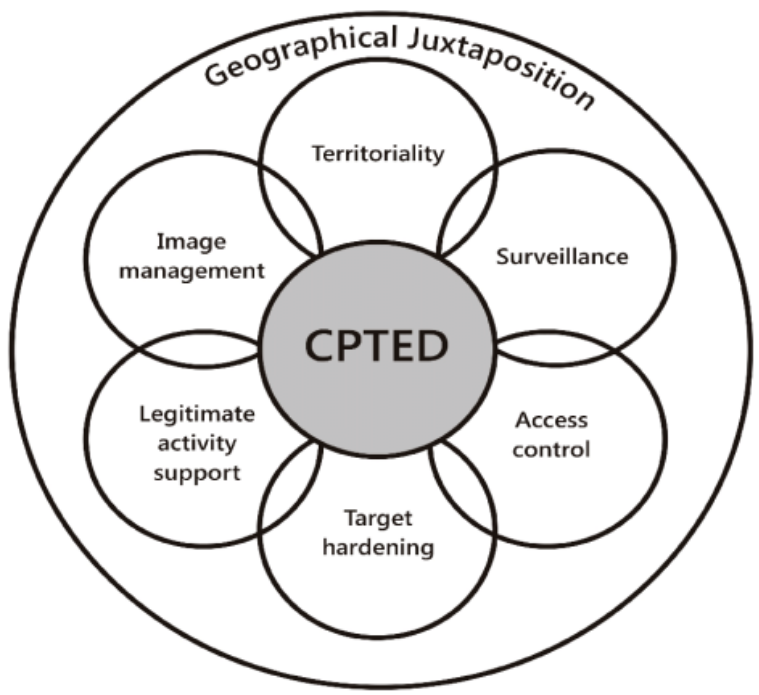

Fig. 1. Principles of the CPTED concept [13].

Territoriality - use landscaping that can separate public and private space. It is possible to use several elements with which we can ensure territoriality. These are divided into symbolic (signs, landscaping, sidewalks) and real (barriers, fences, walls) [13, 14, 20].

Natural Surveillance - the principle is that the perpetrator is "always insight". These include the correct placement and design of windows, lighting, and landscaping. This makes it possible to observe the perpetrators and make them easier to detect. This principle serves as a deterrent. Natural Surveillance can be provided by formal (CCTV - Closed Circuit Television) or the informal elements mentioned above $[13,14,20]$.

Image management - assumes that if the surroundings of the building are maintained, it discourages the perpetrator from committing a crime. Regular maintenance ensures the functioning of the physical environment $[13,14,20]$. 
Access control - is based on the restriction of access roads to potential perpetrators. It can be done in the form of various natural elements (shrubs, trees, greenery) or through formal arrangements (gateway, doors) [13, 14, 20].

Other theories that focus on crime prevention through environmental design include situational crime prevention and environmental criminology. Although there is no way to accurately calculate the number of incidents involving physical design or management, it is estimated that 10 to 15 percent of crimes have been reduced due to environmental design and management components [12]. In England, the Secured by Design (SBD) program has been created, which deals with the creation of a secure environment. It is based on the design of the right environment design, for the need of reducing crime. The SBD focuses on the following principles [21]:

- Physical Security,

- Surveillance,

- Access/egress,

- Territoriality,

- Management and Maintenance.

An example of the correct application of crime prevention design is Olympic Park, the Village, and Westfield Shopping Center in London. The design of this environment has been designed to limit the opportunity to commit crime or terrorism during the Olympic Games. The design was focused mainly on lighting, fences with bright bands, low plants, or CCTV systems. These measures reduced the number of crimes to a minimum during the event [22].

In the article, we will use mainly the principles of the CPTED concept.

\section{Methods}

The article is focused on showing out the impact of globalization and its effects on the development of the urban environment and its security. Security is one of the important aspects of human development in a globalized world. The sensation of security and the level of crime can be included among the objective and subjective social indicators of quality of life. Crime and violence can endanger the physical security of the individual, even if these risks do not materialise. Subjective perceptions of this threat may lead to feelings of insecurity that can compromise the quality of life. Based on statistical data, the article evaluated the impact of crime perception on the type of built environment. The results were obtained from European Union statistics and provide information on the subjective perception of the level of crime. Subsequently, the share of the population that perceived crime according to the area where they live was evaluated. It turned out that, especially in cities, there is a higher proportion of people who perceive crime. In the practical part, the urban environment was assessed in terms of compliance with the principles of the CPTED concept. The object of the research was the city park in Žilina. The park is a public space, which can be described as a magnet of crime. Subsequently, the financial costs required to meet the individual principles were quantified. The results of financial costs pointed out the possible economic impacts of individual changes in the physical environment for a selected type of urban environment.

\section{Results}

The assessment of the quality of life in cities depends on several social and economic factors. Whether it is the availability of financial resources, the quality of infrastructure, access to markets, or the availability respectively use of modern technologies. An important 
factor, that affects social and economic factors, is security. This is mainly influenced by the development of crime in selected environments. An example of macroeconomic problems due to crime can be the case of Mexico City. In this case, tourism is affected by crime, which results in direct financial losses for the city.

Developments, which are also caused by the effects of globalization, suggest that the population of the EU's urban regions increased by 3.8 million between 2014 and 2019. An increase in urban population has been recorded in fourteen EU countries. This is also one of the reasons why it is necessary to focus on the urban environment in connection with security. Another reason is the analysis of the perception of crime according to the degree of urbanization in 2018, which was carried out among the inhabitants of the EU Member States. The results showed that the most perceived crime is among people living in cities (17.4\%), followed by suburbs with $9.2 \%$ and the rural area with 5.8\% [23]. The results show that the highest perceptions of crime, violence, or vandalism are recorded among people living in cities. The following graph (Fig. 2.) shows the individual values of crime perception according to the degree of urbanization.

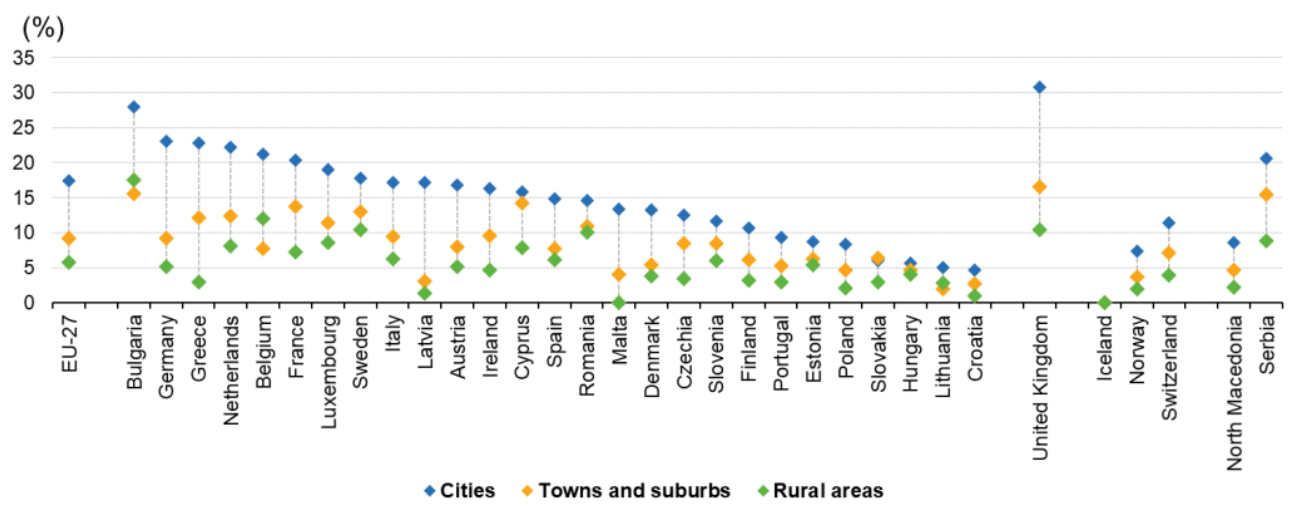

Fig. 2. The proportion of the population that perceived crime, violence, or vandalism according to the degree of urbanization [23].

One way to meet this challenge is to strengthen urban planning aimed at reducing crime. In the article, we focused on a selected part of the city, where we analyzed compliance with the principles of the CPTED concept and the financial costs associated with their compliance. The selected urban environment was the city park in Žilina. "Ludovít Štúr" Park is visited by many people as part of their leisure or sports activities. The park has undergone a complete renovation. The total cost of the reconstruction of the park cost more than 1 million $€$. In the article, we focused only on those costs that were linked to selected principles of the concept (Territoriality, Natural Surveillance, Image management over access control).

Table 1. CPTED principles and their financial costs in "L'udovít Štúr" Park.

\begin{tabular}{|c|c|c|c|}
\hline Type of reconstruction & Financial costs & CPTED principles & Description \\
\hline $\begin{array}{c}\text { New railings and } \\
\text { modification of the } \\
\text { stream bank }\end{array}$ & $4600 €$ & Territoriality & $\begin{array}{c}\text { The individual } \\
\text { elements separate the } \\
\text { environment of the } \\
\text { park from the } \\
\text { surrounding } \\
\text { environment (ways, } \\
\text { buildings). }\end{array}$ \\
\hline
\end{tabular}




\begin{tabular}{|c|c|c|c|}
\hline Type of reconstruction & Financial costs & CPTED principles & Description \\
\hline $\begin{array}{c}\text { Street lighting and } \\
\text { installation work }\end{array}$ & $257660 €$ & Natural Surveillance & $\begin{array}{c}\text { Lighting helps } \\
\text { maintain natural } \\
\text { surveillance }\end{array}$ \\
\hline $\begin{array}{c}\text { IP cameras and } \\
\text { installation work }\end{array}$ & $104733 €$ & Natural Surveillance & $\begin{array}{c}\text { Cameras are among } \\
\text { the formal elements of } \\
\text { natural surveillance }\end{array}$ \\
\hline Green maintenance & $320000 €$ & $\begin{array}{c}\text { Maintenance } \\
\text { discourages the } \\
\text { commission of a } \\
\text { crime. }\end{array}$ \\
and Natural \\
Surveillance & $\begin{array}{c}\text { Properly landscaped } \\
\text { greenery helps } \\
\text { maintain natural } \\
\text { surveillance. }\end{array}$ \\
\hline $\begin{array}{c}\text { Reconstruction of the } \\
\text { fountain }\end{array}$ & $250000 €$ & Image management & $\begin{array}{c}\text { Maintenance of the } \\
\text { environment } \\
\text { discourages the } \\
\text { commission of a } \\
\text { crime. }\end{array}$ \\
\hline
\end{tabular}

In addition to the mentioned principles of the CPTED concept, other elements are also used in the park. Territoriality is also maintained through real barriers, specifically the built wall separating the park from the main road. There are precisely defined sidewalks, which also ensure the principles of territoriality. For Image management, the park also uses waste bins, maintenance of the statue, fountain, and its environs.

\section{Discussion}

In the article, we analyzed a selected part of the city, specifically the "L'udovít Štúr" Park. In this example, we assessed compliance with the principles of the CPTED concept and the financial costs of implementation. These financial costs were invested in the overall reconstruction of the park. The financial costs listed in the table are basic [24]. As part of the reconstruction of the park, many associated works were carried out, which individual values can increase, or decrease. During the maintenance of greenery, several implementation periods were included, as the maintenance is performed at regular intervals. It was important to point out the possibility of applying the principles of the CPTED concept and its possible financial costs.

Within the urban environment, there are many different environments (residential, industrial, relaxing, etc.). Consequently very difficult to recommend the thorough elements and their financial costs that need to be observed for selected types of environments in conjunction with the principles of the CPTED concept [25]. Nevertheless, it is important to realize that the physical design and management of the built environment play an important role in reducing opportunities for crime. It is therefore appropriate to apply selected concepts and its principles if we want to prevent crime as effectively as possible.

\section{Conclusion}

Increasing the number of people moving to cities can bring more positives, but also negatives. For such cities, new and new challenges associated with this development are 
constantly emerging. Whether it is infrastructure, education, jobs, etc. One of the most important elements of this development is also ensuring the security of citizens and their property. An increasing number of people may also lead to a higher increase in crime. It is therefore necessary to address this challenge. One way to prevent crime in an urban environment is to use it properly. In the article, we pointed out the relationship between the development of the urban environment and crime prevention. Several options for crime prevention based on the physical environment have been described. One of these possibilities is the concept of CPTED. In the article, we assessed the application of selected principles of the CPTED concept on a specific example. Subsequently, the financial costs of implementing such an environment were also assessed. The results showed the need for crime prevention solutions in the urban environment and the complexity, respectively effectiveness of its solution through architectural modifications.

This paper was supported by project VEGA 1/0768/19.

\section{References}

1. Hofreiter, L. (2016). Bezpečnostné prostredie súčasného sveta. Zlín : Radim Bačuvčík - VeRBuM.

2. European Commission. (2020, Septembre 10). Policy on the Urban Environment Overview. Retrieved from : https://ec.europa.eu/environment/urban/index_en.htm

3. Meerow, L., Newell, J. P., Stults, M. (2016). Defining Urban Resilience: A Review. Landscape and Urban Planning, 147, 38-49.

4. Nowakowski, W., Lukasik, Z., Bojarczak, P. (2016). Technical safety in the process of globalization. In T. Kliestik (Ed.), Proceedings of 16th International Scientific Conference on Globalization and its Socio-Economic Consequences (pp. 1571-1578). Zilina : EDIS.

5. Lak, A., Hasankhan, F., Garakani, S.A. (2020). Principles in practice: Toward a conceptual framework for resilient urban design. Journal of environmental planning and management, 63(12), 13246-13262.

6. Siser, A. Soltes, V., Kubas, J. (2016). Crime prevention in the education process at high schools. In L. G. Chova, A. L. Martinez \& I. C. Torres (Eds.), Proceedings of the 8th International Conference on Education and New Learning Technologies (EDULEARN) (pp. 5803-5808). Barcelona, Spain : Edulearn Proceedings.

7. Zaidi, S.A.H., Wei, Z., Gedikli, A., Zafar, M.W., Hou, F., Iftikhar, Y. (2019). The impact of globalization, natural resources abundance, and human capital on financial development:Evidence from thirty-one OECD countries. Resources policy, 64, 14761476.

8. Kubas., J., Stofkova, Z. (2017). Application of Some Research Methods to Determine the Level of Safety in Municipalities. In E. Soriano, C. Sleeter, M. A. Casanova \& V. C. Cala (Eds.), Proceedings of the 7th International Conference on Intercultural Education - Education, Health and ICT - From a Transcultural Perspective (EDUHEM) (pp. 242-248). Almeria, Spain : Univ Almeria.

9. Hofreiter, L., Byrtusova, A., Zvakova, Z., Jangl, S. (2016). Ontological Aspects of Security Protection. In H. Zhang (Ed.), Proceedings of the 3rd international conference on management innovation and business innovation (ICMIBI 2016) (pp. 914). Manila, Philippines : Lecture Notes in Management Science. 
10. Ministerstvo vnútra Slovenskej republiky. (2020, Septembre, 13). Štatistika kriminality v Slovenskej republike za rok 2020. Retrieved from: https:/www.minv.sk/?statistikakriminality-v-slovenskej-republike-csv

11. Boros, M., Kutaj, M., Maris, L., Velas, A. (2018). Development of security at the local level through practical students training. In L. G. Chova, A. L. Martinez \& I. C. Torres (Eds.), Proceedings of the 12th international technology, education and development conference (INTED) (pp. 725-729). Valencia, Spain : Inted Proceedings.

12. Enhancing urban safety and security. (2007). United Nations Human Settlements Programme (UN-Habitat), London, UK.

13. Cozens P., Love, T. (2015). A Review and Current Status of Crime Prevention through Environmental Desing (CPTED). Journal of Planning Literature, 1-20.

14. Hofreiter, L. (2016). Manažment ochrany objektov. Žilina: EDIS.

15. Armitage, R., Monchuk, L. (2020). What is CPTED? Reconnecting Theory with Application in the Words of Users and Abusers. Policing - A journal of policy and practice, 13(3), 312-330.

16. Molaeri, P., Hashempour, P. (2020). Evaluation of CPTED principles in the housing architecture of rural areas in the North of Iran (Case studies: Sedaposhte and Ormamalal). International journal of law crime and justice, 62, 100405.

17. Arabi, M.; Naseri, T. S; Jahdi, R. 2020. Use All Generation of Crime Prevention through Environmental Design (CPTED) for Design urban Historical Fabric (Case Study: The central area of Tehran Metropolis, Eastern Oudlajan). AIN SHAMS ENGINEERING JOURNAL 11(2), 519-533.

18. Newman, O. (1973). Defensible Space: Crime Prevention through Urban Design, New York : Macmillan.

19. Jeffery, C. R. (1971). Crime prevention through evironmental design. Beverly Hills, CA : Sage Publications.

20. Lab, S. P. (2020). Crime Prevention - Approaches, Practices, and Evaluations. 5nd edn. New York: Routledge.

21. Armitage, R. (2000). An evaluation of secured by design housing within West Yorkshire. Police Research, Reducing Crime, Special Interest Series. Home Office, PRC Unit Publications, 1-4.

22. Secured by Design. (2020, August 13). Delivering a Safe and Secure Olypmic and Paralympic Games, London 2012. Retrieved from: https://www.securedbydesign.com/guidance/research-case-studiesguidance/delivering-a-secure-olympics-2012/viewdocument/37

23. Eurostat. (2020, Septembre 3). Quality of life indicators - economic security and physical safety. Eurostat - Statistics Explained. Retrieved from: https://ec.europa.eu/eurostat/statistics-explained/index.php?title=Main_Page

24. Mesto Žilina - elektronická verejná správa. (2020, Septembre 13). Zverejňovanie zmlúv. E-governance. Retrieved from: https://egov.zilina.sk/Default.aspx?NavigationState=781\%3a0\%3a

25. Kubas, J., Velas, A., Siser, A. (2017). Implementation of multi-criteria decision making as the method used to achieve optimal level of Security in local municipalities. In H. Zhang (Ed.), Proceedings of the 4th icmibi international conference on training, education, and management (ICMIBI-TEM 2017) (pp. 371-375). Dubai: Lecture Notes in Management Science. 